\title{
Massive Bleeding and Massive Transfusion
}

\author{
Andreas Meißner ${ }^{\mathrm{a}} \quad$ Peter Schlenke ${ }^{\mathrm{b}}$ \\ ${ }^{a}$ Klinik für Anästhesie, Intensiv- und Notfallmedizin, Schmerztherapie und Palliativmedizin, Klinikum Stadt Soest, \\ ${ }^{\mathrm{b}}$ Institut für Transfusionsmedizin und Transplantationsimmunologie, Universitätsklinikum Münster, Germany
}

\section{Keywords}

Bleeding complication · Coagulation factors · Colloids .

Erythrocyte transfusion. Fresh frozen plasma.

Massive transfusion - Thrombocytes . Volume replacement

\section{Summary}

Massive bleeding in trauma patients is a serious challenge for all clinicians, and an interdisciplinary diagnostic and therapeutic approach is warranted within a limited time frame. Massive transfusion usually is defined as the transfusion of more than 10 units of packed red blood cells (RBCs) within $24 \mathrm{~h}$ or a corresponding blood loss of more than 1- to 1.5-fold of the body's entire blood volume. Especially male trauma patients experience this life-threatening condition within their productive years of life. An important parameter for clinical outcome is to succeed in stopping the bleeding preferentially within the first $12 \mathrm{~h}$ of hospital admission. Additional coagulopathy in the initial phase is induced by trauma itself and aggravated by consumption and dilution of clotting factors. Although different aspects have to be taken into consideration when viewing at bleedings induced by trauma compared to those caused by major surgery, the basic strategy is similar. Here, we will focus on trauma-induced massive hemorrhage. Currently there are no definite, worldwide accepted algorithms for blood transfusion and strategies for optimal coagulation management. There is increasing evidence that a higher ratio of plasma and RBCs (e.g. 1:1) endorsed by platelet transfusion might result in a superior survival of patients at risk for trauma-induced coagulopathy. Several strategies have been evolved in the military environment, although not all strategies should be transferred unproven to civilian practice, e.g. the transfusion of whole blood. Several agents have been proposed to support the restoration of coagulation. Some have been used for years without any doubt on their benefit-to-risk profile, whereas great enthusiasm of other products has been discouraged by inefficacy in terms of blood transfusion requirements and mortality or significant severe side effects. This review surveys current literature on fluid resuscitation, blood transfusion, and hemostatic agents currently used during massive hemorrhage in order to optimize patients' blood and coagulation management in emergency medical aid.

\section{Schlüsselwörter \\ Blutungskomplikation - Koagulationsfaktoren · Kolloide · Erythrozytentransfusion - Gefrorenes Frischplasma . Massivtransfusion - Thrombozyten · Volumenersatz}

\section{Zusammenfassung}

Die Massivblutung eines Traumapatienten ist für alle Kliniker eine große Herausforderung und erfordert ein interdisziplinäres Vorgehen sowohl bei Diagnostik und Therapie innerhalb kürzester Zeit. Die Massivtransfusion ist definiert als die Transfusion von mehr als 10 Blutkonserven innerhalb von $24 \mathrm{~h}$ oder als der korrespondierende Verlust des 1- bis 1,5-fachen des Körperblutvolumens. Insbesondere männliche Traumapatienten erleiden diesen lebensbedrohlichen Zustand in ihren produktiven Jahren. Entscheidend für den weiteren Verlauf ist eine effektive Blutstillung in den ersten $12 \mathrm{~h}$ nach Krankenhausaufnahme. Die begleitende Koagulopathie wird durch das Trauma selbst verursacht und durch Verbrauch und Dilution von Gerinnungsfaktoren weiter verstärkt. Obwohl bei Massivblutungen bestimmte Aspekte ihrer Verursachung wie z.B. ihr verletzungs- bzw. chirurgisch bedingtes Auftreten berücksichtigt werden müssen, ist die "Basis-Strategie" gleich. Derzeit gibt es weltweit keine allgemein anerkannten Transfusionsalgorithmen und Strategien zum Gerinnungsmanagement für solche Patienten. Mehr und mehr Evidenz lässt einen Überlebensvorteil für gefährdete Patienten mit einem Risiko für Trauma-assoziierte Gerinnungsstörungen vermuten, die mit gefrorenen Frischplasmen und Erythrozytenkonzentraten in einem definierten Verhältnis (z.B. 1:1) und ergänzt durch Thrombozytenkonzentrate behandelt werden. Einige Erkenntnisse sind dabei im militärischen Umfeld gewonnen worden. Nicht alle - wie etwa die Verwendung von Frischblut - sollten ungeprüft auch im zivilen Sektor Anwendung finden. Zahlreiche Substanzen sind für die Verbesserung der Gerinnung verwendet worden. Dabei sind manche Präparate seit Jahrzehnten im Gebrauch ohne Zweifel an ihrem positiven Nutzen-Risiko-Verhältnis, während bei anderen enthusiastische Erwartungen durch Unwirksamkeit in Bezug auf den Transfusionsbedarf, die Sterblichkeit oder wegen schwerwiegender Nebenwirkungen enttäuscht wurden. Dieser Übersichtsartikel versucht, einen Literaturüberblick über die Flüssigkeitssubstitution, Bluttransfusion und hämostatisch wirksame Medikamente während einer Massivblutung zu geben, um die Patientenbehandlung mittels Blutkomponenten und Gerinnungsfaktoren in der Notfallsituation zu verbessern.

\section{KARGER \\ Fax +497614520714 \\ Information@Karger.de}

www.karger.com (c) 2012 S. Karger GmbH, Freiburg

1660-3796/12/0392-0073\$38.00/0

Accessible online at:

www.karger.com/tmh
Prof. Dr. med. Andreas Meißner

Klinik für Anästhesie, Intensiv- und Notfallmedizin,

Schmerztherapie und Palliativmedizin Klinikum Stadt Soest

Senator-Schwartz-Ring 8, 59494 Soest, Germany

Tel. +49 2921 901-383, Fax -818

a.meissner@klinikumstadtsoest.de 


\section{Introduction}

Uncontrolled and massive hemorrhage is still one of the major challenges in the surgical and anesthesiological field. Trauma is the leading cause of death for individuals between the age of 18 and 45, within the most productive years of life. These patients represent the most important population at risk for the development of coagulopathy due to structural disruption and uncontrolled hemorrhage. It is therefore necessary to put more efforts on an effective therapy and timing of the intervention because $15-20 \%$ of the resulting deaths which occur within the first $12 \mathrm{~h}$ of hospital admission might be preventable. This review summarizes the basic knowledge about trauma-induced hemorrhage and coagulopathy and the still ongoing, controversial debate of the best-fit treatment options. Beginning with the first line-therapy of fluid resuscitation - already profoundly influencing homeostasis -, we will discuss pro-coagulant preparations finally ending with packed red blood cells (pRBCs) and platelets.

Principally, the effective treatment for massive transfusion, which is defined as transfusion of more than 10 units of pRBCs within $24 \mathrm{~h}$ of injury [1] (fig. 1), is replacement therapy. Other authors [2] have developed a classification scheme for hemorrhage, stratifying blood loss from stage 1 (less than $15 \%$ of total circulating blood volume) to stage 4 (more than $40 \%$ of total circulating blood volume). Young adults in good condition may compensate a loss of $50 \%$ of the circulating blood volume but may then develop sudden cardiovascular collapse when the physiological scope of tolerance is passed over and further compensatory mechanisms fail. In contrast, elderly people may tolerate much less blood loss, depending upon a huge variety of comorbidities.

Rather the prevention than the treatment of accompanying coagulopathy is the main issue in decreasing the number of fatal outcomes in this group of trauma patients. Active hemorrhage as a result of major injuries is life-threatening and leads to hemorrhagic shock and exsanguination if not treated immediately. Especially in trauma patients the precise estimation of the actual blood loss is mostly uncertain. Bleeding may be stopped temporarily by external compression and/or tourniquets. However, surgical or interventional (e.g. arterial embolization) repair is required for final hemorrhage control [3].

\section{Definition of massive transfusion}

- Transfusion of $\geq 10$ RBC-units within $24 \mathrm{~h}$ or

- Blood loss > 1- to 1.5-fold of the patients' blood volume

General aspects of massive transfusion

- Low and continuously decreasing incidence

( $\sim 2 \%$ of all emergencies in a hospital of maximun medical care)

- Majority of male patients below 45 years (productive age)

- High mortality especially for trauma-related massive hemorrhage

Fig. 1. Definitions and key issues in trauma.

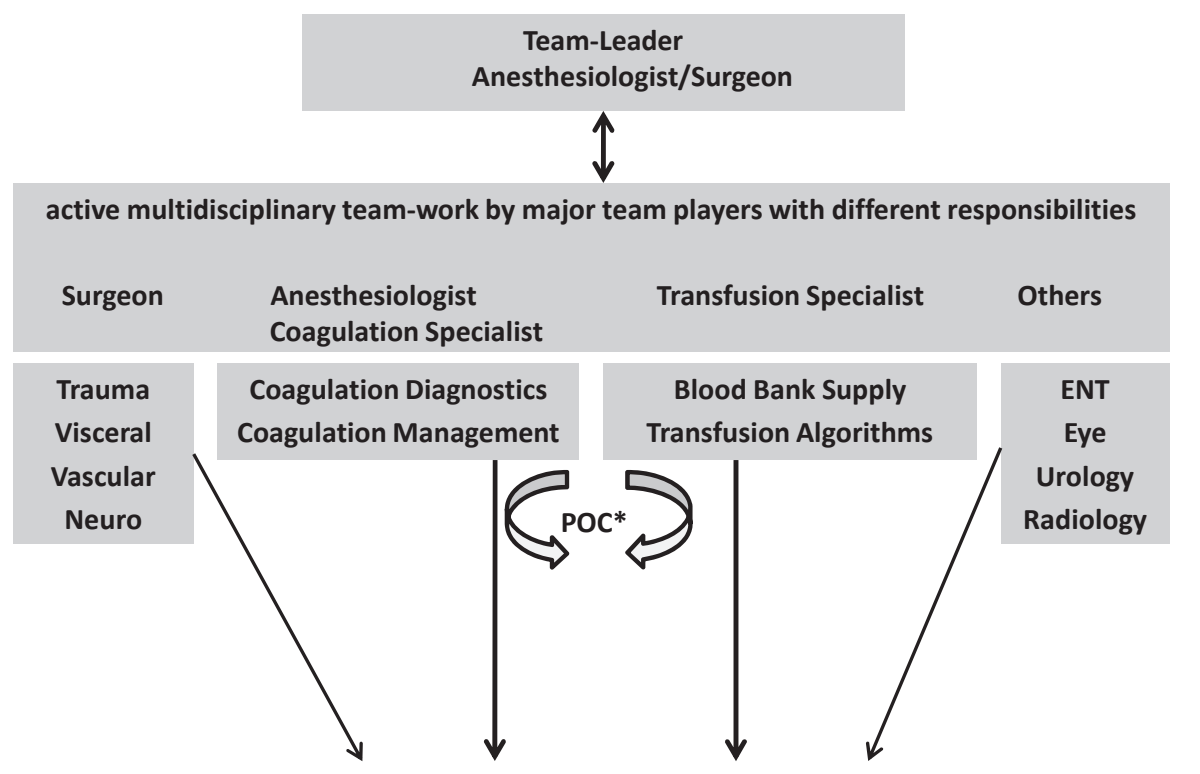

Common goal of the team

Treatment of patients with massive hemorrhage and trauma-induced coagulopathy

Fig. 2. Team players, elementary diagnostics, and their function in the trauma team.
* Point-of-care diagnostics such as thromboelastography and impedance aggregometry 


\section{Organizational Issues}

Before putting the focus on the pathophysiology of massive transfusion, an organizational aspect needs to be emphasized. All hospitals, especially those with emergency departments which might be primarily confronted with patients with major hemorrhage, should have at least a protocol that includes all major facility-specific clinical, laboratory and logistic responsibilities [4]. A schematic illustration is given in figure 2. In this context, the establishment of in-house transfusion policies and detailed standard operating procedures are helpful instruments to manage cases of emergency in a more objective and predictable manner. There should be a team leader responsible for assessing and coordinating a series of diagnostic and therapeutic measures, including all issues of an optimal patients' blood management. It is necessary to allocate a person to convey blood samples and blood components between the laboratory and the area the patient is treated and vice versa. This includes also the accurate handling of the bedside test and the check-up of each blood component prior to application. In parallel, it is mandatory to warrant sufficient intravenous access at appropriate size either peripherally or centrally. Rapid transfusion devices may be used when large volumes have to be transfused quickly as in massive hemorrhage. The volume should be monitored regularly throughout the transfusion to ensure that the expected volume is delivered at the required rate [4]. In case of failure, intra-osseous or surgical access might be useful.

One major difficulty is that only a small percentage (1-2\%) of all trauma victims suffer from massive hemorrhage, . which results in a case load far below 100 per year even in highly frequented trauma centers. This makes training and acquiring expertise quite difficult. There are several issues to discuss in this review, although guidelines have been established to provide clinicians with a rule for the treatment in these cases. The most recent and extensive guideline is given by the German Society of Trauma Surgeons, but unfortunately is only published in German [5].

\section{Fluid-Associated Issues}

Fluids are the first-line therapeutic approach; different fluids are used for resuscitation. There is still an ongoing discussion about the optimal fluid used in patients with trauma-induced coagulopathy for successful resuscitation [6]. This issue might need a thorough new work-up as it is unknown how common scientific fraud is especially in this field. Withholding fluid in low perfusion situations as well as crystalloid infusions are only seen in conjunction with formation of interstitial edema, dilutional acidosis, and severe impairment of microcirculation and a consequent increase in mortality [7]. Less impairment has been shown with conventional administration of colloids.

Generally, synthetic colloids such as hydroxyethyl starch (HES) are widely used for intravascular volume therapy in surgical, emergency, and intensive care patients and are believed to be more effective than crystalloids as they meet the hemodynamic endpoints [8]. There have been some concerns about the influence of colloids on coagulation, renal failure, and pruritus. As HES is used in different preparations, currently there is no generally accepted conclusion available about the risk-benefit assessment [8]. The HES are differentiated by three numeric characters, the first representing the concentration in percent, the second the average molecular weight, and the third the molar substitution. The modern preparations with a lower molecular substitution such as $6 \%$ HES 130/0.4 seem to have a lesser effect on coagulation [9].

The main and traditional concept of resuscitation in acutely bleeding trauma patients was aggressive fluid administration aimed at restoring intravascular blood volume. This approach, however, may contribute to further blood loss by increasing hydrostatic pressure on the clots, an aggravation of hypothermia, and a further dilution of coagulation factors. Other approaches dealing with a concept of delayed fluid resuscitation in patients with penetrating injuries until the arrival in the operating room was first described by Bickell et al. [10]. Although this concept has been expanded from patients with penetrating injuries to blunt trauma, there are conflicting appreciations on the resulting effects. Especially prolonged hypotension results in poor outcome in animal studies [7]. The current military doctrine and training emphasizes minimizing fluid and blood product delivery in the pre-hospital or pre-OP theater setting in combat casualties who have a palpable radial pulse and a normal mental status [11]. On the other hand, the concept has to be used with caution as the prolonged duration of shock may deteriorate organ function [12] and further aggravate the extent of coagulopathy. In patients with head injury the incidence of secondary ischemic insults might be increased [13].

\section{Key Parameters and Assessment of Trauma-Induced Coagulopathy}

Beside the discussion about the substitution of coagulation factors and blood components, there is evolving knowledge that trauma itself has time- or incident-depending effects on coagulation [14]. Initially the combination of traumatic injury and tissue hypoperfusion results in a coagulopathy associated with a reduction in protein $\mathrm{C}$ levels. Activated protein $\mathrm{C}$ exerts its anticoagulant effects by irreversibly inactivating factors $\mathrm{Va}$ and VIIIa [15]. A further anticoagulant activity is exerted by the de-activation of plasminogen activator inhibitor (PAI-1), resulting in enhanced fibrinolysis [16]. In addition to its anticoagulatory effects, protein $\mathrm{C}$ proteolytically activates the cell surface receptor protease-activated receptor-1 (PAR-1) and thus generates several cytoprotective effects by increasing the anti-inflammatory properties, anti-apoptotic activity, and protective function of the endothelial barrier, all being required for survival in acute shock [14]. Taken together, early post- 


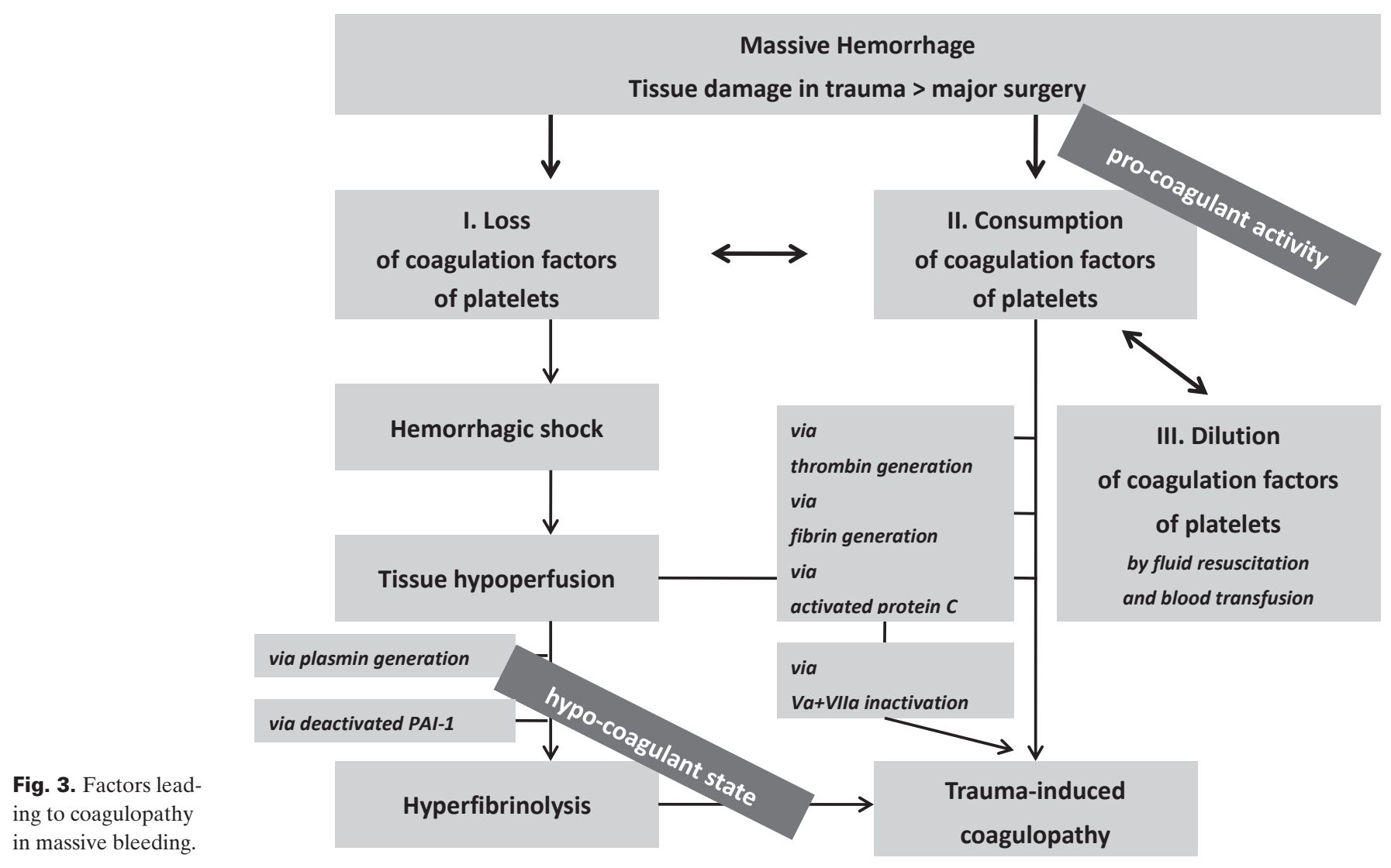

traumatic coagulopathy is characterized by systemic anticoagulation/coagulopathy in conjunction with hyperfibrinolysis [17]. An illustration of these changes is given in figure 3 .

Acidosis is often seen in massively transfused patients. There are two major components responsible for this pathologic state: anaerobic metabolism (lactate production) in hypoperfused tissues and excessive administration of chloride as $\mathrm{NaCl}$ or $\mathrm{NaCl}$-based colloids. The infusion of these solutions should therefore be minimized [18]. Acidosis is responsible for impaired coagulation as the optimal range for the function of coagulation is left. For example, the enzyme activity of factor VIIa drops down to $10 \%$ of the initial level at a $\mathrm{pH}$ of 7.0 instead of 7.4. At a pH below 7.4, also platelets change structures and shape, forming spheres without any pseudopodia that are responsible for induction of coagulation [19]. Thrombin generation itself is inhibited [20]. On the other hand, a correction of acidosis does not lead automatically to a normalization of coagulation [20]. Acidosis furthermore leads to an increased degradation of fibrinogen [17].

Therefore, during the volume substitution of hemorrhage, acidosis or aggravation of acidosis in terms of dilutional coagulopathy or dilutional acidosis must be avoided. Balanced solutions show a potential base excess of $0 \mathrm{mmol} / \mathrm{l}$, i. E., with no influence on the patient's acid base status after infusion plus metabolism of the anions [21]. The best strategy to prevent acidosis is to avoid $\mathrm{NaCl}$ and to treat hemorrhage-associated acidosis is the use of plasma-equivalent electrolyte-based solutions.
Hypocalcemia is often linked with acidosis and aggravated by citrate. The content of free ionized $\mathrm{Ca}^{2+}$, which is necessary for the assembly of coagulation factors on the surfaces of platelets and injured endothelium, is inversely correlated with blood $\mathrm{pH}$ [22]. Calcium ions are essential not only for fibrin polymerization and platelet function but also for fibrinolysis and activation of the protein $\mathrm{C}$ system. Citrate-containing blood components, especially fresh frozen plasma (FFP), and in addition synthetic colloids promote the development of hypocalcemia [23]. Lactate, which usually increases during massive bleeding, causes a linear decrease in $\mathrm{Ca}^{2+}$ concentration. This phenomenon is estimated by an increase of $0.05 \mathrm{mmol} / 1 \mathrm{Ca}^{2+}$ pro $1 \mathrm{mmol} / 1$ lactate. Thus, a concentration of $10 \mathrm{mmol} / \mathrm{l}$ lactate results in a reduction $0.5 \mathrm{mmol} / 1 \mathrm{Ca}^{2+}[24,25]$ and thus usually in a relevant severe hypocalcemia requiring urgent therapy. The application of lactate-containing fluids like Ringer's lactate should therefore be diminished. All solutions should contain at least physiologic levels of calcium.

Although not clearly established in the clinical context, validation studies indicate a storage time-dependent base deficit in erythrocyte concentrates. This reaches a level of almost $50 \mathrm{mmol} / \mathrm{l}$ base excess after 42 days, which results in a likely decreased chance of survival, where balanced $\mathrm{pH}$ is one of the major survival criteria. Therefore any solution or blood product used in this situation should not contribute to hypocalcemia or acidosis. 


\section{Framework of trauma-induced coagulopathy}

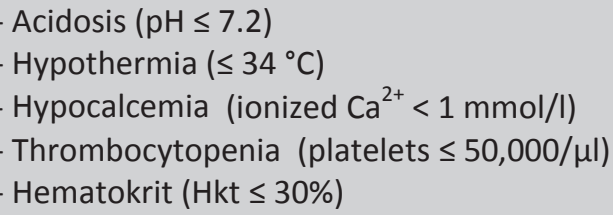

Fig. 4. These key parameters should always be kept in the target range of normal or in specific target ranges to optimize coagulation. This also applies before special agents like factor VII are applied.

One important issue in the reduction of blood loss is the maintenance of euthermia [23]. A reduction of the temperature to $34{ }^{\circ} \mathrm{C}$ or lower might increase the perioperative blood loss as reported for hip surgery patients [26]. A further reduction leads to significant deteriorations as enzymatic function slows down, which is the key issue in the coagulation cascade. The cellular component is also impaired as adhesion and aggregation are decreased which might also be represented by enzymatic function in the granules. It is important to note that a body temperature-related impairment of coagulation in vivo is not seen in any coagulation test as these are performed in normothermia. If performed under 'real' or measured temperature conditions, platelets undergo morphological changes [23], which are responsible for impaired coagulatory function. There is an estimation that every $1{ }^{\circ} \mathrm{C}$ temperature reduction results in a reduction of $10 \%$ coagulatory function [27]. In contrast, a study by Wolberg et al. [28] reported that coagulation enzyme activities and platelet activation are not significantly decreased at $33{ }^{\circ} \mathrm{C}$ versus $37^{\circ} \mathrm{C}$. The key parameters which significantly influence the coagulation activity are highlighted in figure 4.

As shown by ROTEM, hypothermia and acidosis synergistically impaired coagulatory function [29]. Therefore, patients in the emergency room or ICU are often covered by upper body warm blankets to prevent cooling down. Furthermore, in all patients undergoing emergency resuscitation all intravenous fluids and blood components should be warmed to $37^{\circ} \mathrm{C}$ to avoid hypothermia [30]. Work flow diagrams and/or transfusion algorithm protocols have to indicate this important recommendation. The greatest benefit is from the controlled warming of RBCs (stored at $4{ }^{\circ} \mathrm{C}$ ) rather than platelets (stored around $22^{\circ} \mathrm{C}$ ) or FFP thawed to $37^{\circ} \mathrm{C}$ [4]. There is no evidence to suggest that transfusion of RBCs, platelets, or FFP through a licensed blood warmer device is harmful. The use of lyophilized plasma is another option. Up to now, no study-based comparison between the use of frozen or lyophilized plasma has been published until now; however from a logistic point of view the latter might be faster ready for use.

Another issue in blood transfusion is the use of appropriate blood warmers [4]. As the Association of Anaesthetists of Great Britain and Ireland points out, blood should only be warmed using approved, specifically designed, and regularly maintained blood warming equipment with a visible thermometer and audible warning. Blood components should never be warmed using improvised devices such as putting the pack in buckets with warm water or in a commercial microwave or on a radiator.

\section{Transfusion-Associated Issues}

Blood transfusions are used as replacement treatment. In contrast to the history of blood donations and blood transfusions after the Second World War until the end of 1980s, currently the blood transfusions can roughly be categorized as noninfectious because transfusion-transmitted infections by HBV, HCV or HIV are actually very rare events as proved by the German Hemovigilance System [31]. The most feared adverse event of blood transfusion is transfusion-related acute lung injury (TRALI) [32]. The incidence of TRALI is much lower $(\sim 1: 10,000)$ than that of other adverse effects such as severe febrile or allergic reactions $(\sim 1 \%)$; however, TRALI is a lifethreatening complication with urgent need of mechanical ventilation in most cases and a TRALI-associated mortality of up to $10 \%$. TRALI is mainly associated with plasma from women. The incidence of TRALI was significantly reduced since plasma from women after pregnancy and/or childbirth were excluded from the donor pool to avoid the transmission of antibodies with specificity mainly against human neutrophil antigens (HNA) or human leukocyte antigens (HLA). A further reduction might also be reached by the use of lyophilisized plasma. In this context and in order to complete the huge diversity of potential adverse events, two other issues, namely the transfusion-associated circulatory overload (TACO) and the transfusion-related immunomodulation (TRIM), have to be mentioned. TRIM is associated with nosocomial infections, impaired wound healing, acute lung injury, multiple organ failure, and increased cancer recurrence on the one hand and with induction of immunotolerance in solid organ transplantation on the other hand. However, evidence is not based on good scientific trials. Therefore, it is impossible to draw any evidence-based clear-cut conclusions.

\section{Treatment of Trauma-Induced Coagulopathy}

\section{Fresh Frozen Plasma}

Due to dilution, consumption, and inhibition of coagulation any major blood loss leads to a hypocoagulable state. There is growing evidence that early and more aggressive replacement of clotting factors reduces mortality and decreases transfusion volume [33-35]. Early standard use of FFP and pRBCs has been shown rather to prevent than to treat a severe dilutional coagulopathy and might contribute to an improved survival. However, in patients with already clinically relevant factor de- 
ficiencies $(<50 \%$ of activity), FFP might not be sufficient to restore coagulatory activity immediately. Furthermore, such a strategy would result in a high risk of TACO. This has been also shown in an interesting mathematical model for FFP transfusion strategies by Ho and colleagues [36]. This group calculated that 1-1.5 units of FFP must be given per unit of pRBC just to correct the dilutional component of coagulation alone. A higher FFP:pRBC ratio would lead to anemia, thrombocytopenia, and an increase of the volume overload. This mathematical model is a 'conservative approach'; deleterious effects of hypothermia, diffuse intravascular coagulation (DIC), and metabolic derangements on coagulopathy have not been taken into account. Taken together, this provides the rationale for an early and more aggressive use of FFP and the subsequent replacement of coagulation factors to causally treat an already existing coagulopathy. However, it is important to point out that - as suggested here - the prophylactic use of FFP in trauma patients anticipating an imminent massive loss of blood is not in line with the current cross-sectional guidelines in Germany [5].

\section{Fibrinogen}

Massive bleeding leads to loss, consumption, and dilution (by volume therapy) of coagulation factors. The first factor falling below a critical level is fibrinogen. The critical threshold was suspected at a level below $100 \mathrm{mg} / \mathrm{dl}$ as shown by Hiippala et al. [37] and was still recommended as a trigger for intervention in a European Guideline in 2007 [38]. Under normovolemic conditions, a loss of the 1.4-fold of the patients'total blood volume and resuscitation with plasma-free solutions is associated with that critical level. One has to take into account that all colloids interfere with the measurement of fibrinogen [39]. FFP is not suitable for a rapid increase in already reduced fibrinogen plasma levels.

A mathematical model for the estimation of fibrinogen levels was developed by Singbartl et al. [40]. In patients undergoing acute normovolemic hemodilution, they were able to show that $20 \%$ of patients already reached critical fibrinogen levels - defined as $<100 \mathrm{mg} / \mathrm{dl}$ - by a blood loss and consequent hemodilution after only $2,000 \mathrm{ml}$. Not surprisingly, this was dependent on the initial fibrinogen content. The whole blood fibrinogen concentration might be estimated by the formula:

$$
F i b_{\text {Blood-Bl }}=F i b_{\text {Blood-Init }} \times e^{-(B L / E B V)}
$$

with $\mathrm{Fib}_{\text {Blood-Bl }}=$ blood fibrinogen concentration after defined blood loss, $\mathrm{Fib}_{\mathrm{Blood}-\mathrm{Init}}=$ initial blood fibrinogen concentration, $\mathrm{BL}=$ blood loss, $\mathrm{EBV}=$ estimated blood volume.

The data on the therapeutic effects is rather sparse. A recent review states: 'There is a lack of evidence to support the use of fibrinogen in trauma patients. Studies in trauma patients are highly warranted' [41].There is still an open debate about the efficacy and necessity of fibrinogen application in acquired fibrinogen deficiency. In severely injured soldiers requiring mas- sive transfusion, however, the amount of fibrinogen given (as a combination of FFP and cryoprecipitate) correlated with rates of survival [42].There are several studies suggesting increased postoperative bleeding if the level of fibrinogen is below the threshold. This has been shown for different surgical specialties like cardiac surgery [43], gynecology [44, 45], and neurosurgery [46]. More recent guidelines and research indicated that the critical threshold might be higher than previously thought. Consequently, a higher target value of $150-200 \mathrm{mg} / \mathrm{dl}$ for fibrinogen was reported $[47,48]$. We therefore recommend in patients with severe blood loss and ongoing bleeding to keep the fibrinogen level in a proactive fashion above $150 \mathrm{mg} / \mathrm{dl}$ to avoid additional decline by further dilution and consumption. Experience showed that a dose of $3 \mathrm{~g}$ fibrinogen is practicable to ensure fibrinogen levels above the indicated threshold, although until now no prospective randomized trial is available which confirms such a dosage to be optimal.

\section{Cryoprecipitate}

Cryoprecipitate is a preparation rich in fibrinogen, factor XIII, von Willebrand factor, and factor VIII and has been used for therapy of fibrinogen or factor XIII deficiency [49]. In Europe, however, the use has been reduced due to the marketing authorization and permanent availability of singlefactor concentrates [50]. As FFP is not sufficient to raise plasma fibrinogen, in the USA and in the UK cryoprecipitate is accepted as alternative for the replacement of plasma fibrinogen [50]. But also in the UK there are critical notes about the lack of clear definition of amounts of fibrinogen content in cryoprecipitate [51]. One unit cryoprecipitate (15 $\mathrm{ml}$ ) per $10 \mathrm{~kg}$ body weight is estimated to increase plasma fibrinogen by $0.5 \mathrm{~g} / \mathrm{l}(50 \mathrm{mg} / \mathrm{dl})$ if there is no further loss or dilution [50]. To enhance the comparability, for an elevation of 1 $\mathrm{g} / \mathrm{l}(100 \mathrm{mg} / \mathrm{dl})$ fibrinogen, one should use $30 \mathrm{ml} / \mathrm{kg}$ resulting arithmetically in more than 21 of FFP volume.

\section{Prothrombin Complex Concentrate}

The prothrombin complex concentrate (PCC) contains vitamin K-dependent coagulation factors II, VII, IX and X, which are essential for the generation of thrombin and natural anticoagulants $\mathrm{C}$ and $\mathrm{S}$. It is widely used for the therapy of inherited coagulation defects or the reversal of vitamin K antagonists [52]. A reduced thrombin formation might be expected if thrombin is reduced below a level of $30 \%$ which is induced by blood loss of 1.5- to 2.0-fold of the blood volume [37]. However, there is no consensus about the use of PCC in the setting of severe bleeding and massive transfusion. In some studies with a small number of patients, the application of PCC was beneficial. In a porcine model with exsanguination and hemodilution, PCC was also effective in correcting dilutional coagulopathy and showed a trend in reducing blood loss after splenic injury [53]. In this model, PCC was more effective than factor VII alone [54]. Factor VII was also inferior in the reversal of vitamin K-induced anticoagulation [55]. 
Although the concentrate might be effective in certain situations, there is doubt concerning the procoagulatory/prothrombotic effects of PCC. This prothrombotic risk might be even aggravated in hemodilution with consequent antithrombin deficiency [56], and a European Guideline does not recommend the use of PCC [38]. One major risk of the repeated use of PCC results from the different half-lives of factor II, VII, IX, and X as well as protein $\mathrm{C}$ and $\mathrm{S}$. Another issue is the different composition of different formulations. A review analyzing 14 studies with 460 patients with warfarin overdose reported seven thrombotic events [57]. But, like in any other clinical situation, one needs to balance the risk of thromboembolism against further bleeding. Thrombus formation related to heparin-induced thrombocytopenia must not be overlooked, although this is nearly impossible during acute trauma.

\section{Recombinant Factor VIIa}

Originally factor VIIa has been developed for patients with different types of hemophilia and inherited factor VIIa deficiency. For a long time, there have been enthusiastic opinions about the use of supraphysiologic doses of recombinant factor VIIa [58]. Off-label use has been published in numerous case reports, cohorts, and some randomized clinical trials [59-61]. The latter demonstrated its clinical usefulness as transfusion requirements were reproducibly and significantly reduced. There was a significant increase of arterial thromboembolic events, in particular in patients where factor VIIa was used off label [62]. The early use was associated with a decreased mortality $24 \mathrm{~h}$ and 30 days after severe combat casualties requiring massive transfusion [63]. However, it is unclear which patients are appropriate candidates for recombinant factor VIIa administration; moreover, neither the appropriate dose nor the thrombotic risks of this agent are completely known, as pointed out in a recent review by cardiac surgeons and anesthesiologists [64]. Therefore, the initial approach has still to focus on the correction of hemorrhagic shock, acidosis, and thrombocytopenia ensuring adequate hemostasis [65]. In patients with trauma-induced coagulopathies, persisting hemorrhage, and ineffective replacement of coagulation factors, the use of recombinant factor VIIa (initial dose of $100 \mu \mathrm{g} / \mathrm{kg}$ body weight) might be indicated as ultima ratio, preferably after an accompanying severe acidosis is successfully treated.

\section{Factor XIII}

The function of factor XIII is the stabilization of the clot by forming covalent bonds between fibrin monomers and by cross-linking alpha-2 antiplasmin, fibrinogen, fibronectin, collagen, and other proteins to enhance the mechanical strength of the fibrin clot and protect the clot from proteolytic degradation [66]. A decreased factor XIII activity leads to reduced clot firmness in thrombelastography (TEG). Hemorrhage as well as coagulopathy have been shown to cause acquired factor XIII deficiency. A study in orthopedic patients has shown that a substitution by colloids leads to a factor XIII activity below $60 \%$ even after moderate blood losses [67]. In intracerebral hemorrhage, a relationship was shown between hematoma growth and low factor XIII levels [68]. An early approach for factor XIII substitution has also been shown for cancer patients undergoing surgery where large intraoperative bleeding is expected. However, taken together the data obtained from the literature are still preliminary. Neither the critical plasma level as indicator for a substitution threshold nor the precise initial dosage is yet established. From a pathophysiological point of view, Poetzsch et al. [69] suggested that plasma levels $<50 \%$ factor XIII should be treated $(25 \mathrm{IU} / \mathrm{kg}$ body weight).

\section{Hyperfibrinolysis and Inhibition}

All injuries or major surgery might lead to hyperfibrinolysis, especially if organs with an increased level of plasminogen activators are involved [14]. Plasminogen activators are released from hypoxic endothelial cells, and plasminogen activator inhibitors are proteolysed by antigen-presenting cells. The usual test is the euglobulin lysis time as the gold standard for the diagnosis of hyperfibrinolysis. This test lasts about $3 \mathrm{~h}$ and is thus not feasible in the acute situation. The ROTEM platform based on the principles of TEG and becomes more and more established as a point of care (POC) method for the detection of hyperfibrinolysis, although it does not have a very high sensitivity.

There are several studies which show a reduction of bleeding by antifibrinolytic agents. Aprotinin has been taken from the market as it was suspicious to cause an increase in mortality [70,71]. The European Guideline on the Management of Bleeding Following Major Trauma [47] suggests the use of tranexamic acid or $\varepsilon$-aminocapronic acid. Tranexamic acid is a lysine analogon, which binds to the lysine-binding area of plasminogen and decreases its activation. Dosing and relevant plasma levels are not well-defined and have a rather large spread. The clinical efficacy has been shown in the CRASH-2 trial [72] where 20,211 trauma patients with substantial bleeding were treated with tranexamic acid or placebo. A bolus of 1 $\mathrm{g}$ was followed by another $1 \mathrm{~g}$ given continuously over the next 8 h. All-cause mortality was $14.5 \%$ in the tranexamic acid group versus $16 \%$ in the placebo group. The mortality related to bleeding was reduced. This was not on the expense of an increase in vascular occlusive events. Transfusion requirements decreased significantly.

The usual recommendation for patients at high risk for bleeding should receive a dose of $10-20 \mathrm{mg} / \mathrm{kg}$ body weight $/ \mathrm{h}$ [73]. This initial dose should be followed by a continuous infusion of tranexamic acid at a dose of $1 \mathrm{~g}$ over $8 \mathrm{~h}$. The infusion of tranexamic acid should be continued as long as the bleeding stops or is under adequate control.

\section{Desmopressin}

Another point of contention is the use of desmopressin in severe bleeding. Desmopressin leads to the release of factor 
VIII and von Willebrand factor from the endothelium by stimulation of extrarenal $\mathrm{V}_{2}$ receptors and might mobilize thrombocytes from the bone marrow [74]. Desmopressin has been successfully used if the patient is suffering from uremia, hepatic disease, or the medication of aspirine. Desmopressin has been used in several clinical settings; the efficacy was limited and inconsistent. One of the major side effects was the development of hypertension. Tachyphylaxis is seen in some cases, but is usually avoided if desmopressin application is limited to $<24 \mathrm{~h}$ [75]. In a meta-analysis desmopressin slightly reduced blood loss, without reducing the proportion of patients receiving transfusions [76]. A Cochrane analysis found the effect to be not convincing [74]. Therefore, desmopressin is not recommended for routine implementation in treating massive hemorrhage and trauma-induced coagulopathy.

\section{Monitoring of Coagulation}

Conventional diagnostic parameters such as prothrombin time, international normalized ratio, and activated partial thromboplastin time fail in predicting trauma-induced coagulopathy or perioperative bleeding complications precisely. In addition, neither disturbances of the primary hemostasis (e.g. platelet dysfunction) nor a condition of hyperfibrinolysis is recognizable by these coagulation tests. Furthermore, the turn-around time is calculated to be between 30 and $90 \mathrm{~min}$. Therefore, one important aim of research in the field of transfusion and coagulation management is the establishment of a 'guide' by a set novel biomarkers and/or easily applicable functional assays which allows for decision-making within reasonable time (i.e. 10-15 min). A promising approach might be the monitoring by ROTEM or TEG. In a recent Cochrane analysis, 9 studies including 776 participants were identified which compared clinical judgment and standard laboratory tests or both in the adult cardiac surgery and liver transplantation setting [77]. There was no beneficial effect of TEG or ROTEM on patient survival. However, there were positive effects in predefined outcomes such as reduced bleeding and reduced proportion of patients requiring transfusion of platelets or plasma and consequently some cost savings . Additionally, there were no negative effects or adverse events by the application of this POC technology. The effects of TEGdriven therapy need a thorough investigation [78]

\section{Packed Red Blood Cells}

There are some aspects in the transfusion of pRBCs which have to be addressed. Usually, transfusion policies of different studies do not advocate RBC transfusion at a hemoglobin level above $10 \mathrm{mg} / \mathrm{dl}$ and always recommend a transfusion if it falls below $6 \mathrm{mg} / \mathrm{dl}$ [79]. In addition, there is an extensive acceptance of a target value ranging between 7 and $10 \mathrm{mg} / \mathrm{dl}$ post transfusion [80]. The upper limit might be sensible in patients with cardiovascular disease, cerebrovascular disease, or
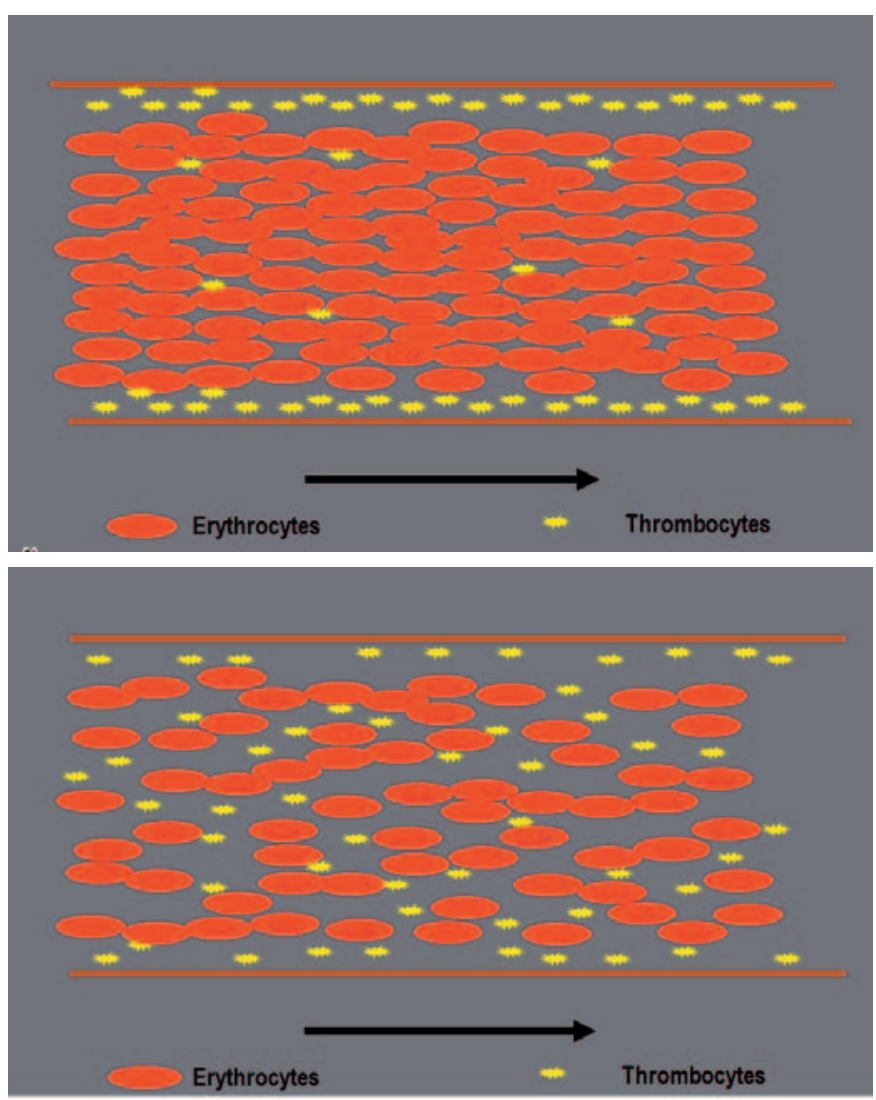

Fig. 5. The margination of thrombocytes might be an important effect in massive bleeding. This effect rather due to hydrodynamic forces rather than collisional forces or volumetric exclusion effects should lead to higher hematocrit values in acute bleeding situations. The upper panel shows well marginated thrombocytes at higher hematocrit values, whereas lower values lead to a distribution within the whole vessel (lower panel).

cerebral trauma. Other monitored aspects in trauma patients with significant hemorrhage are tachycardia, hypotension or an increased oxygen extraction ratio expressed by central venous oxygen saturation below 60 , an increase of lactate, and ST segment depression in the ECG. Simultaneously, time course of blood loss and ongoing losses as well as hemodynamic disturbances should be included in the decision-making whether to transfuse blood components or not in sufficient time, especially in those patients in whom a transfusion avoidance strategy was primary chosen and physiological scope is already utilized so that the circulator failure occurs suddenly. Other determining factors are the properties of the coagulation cascade and wall shear rates in blood vessels at higher hemoglobin levels [81]. The P-selectin expression of platelets is dependent on the hematocrit [82]. There might be a better function of thrombocytes as first-line coagulation at higher hemoglobin levels making a point for liberal and prohemostatic transfusion regimens. Margination is seen to occur due to hydrodynamic forces rather than collisional forces or volumetric exclusion effects [83]. However, neither the optimal hematocrit for this interaction of RBCs, thrombocytes, and 
the vessel wall is known nor data from well-designed clinical trials are currently available. One study suggests a hematocrit in the range of $35 \%$ [84] which is well above a level necessary for optimal cardiovascular function and might interfere negatively with peripheral perfusion and dilutional coagulopathy. A schematic illustration of this effect is given in figure 5 .

In very recent publications, there is an ongoing debate about a renaissance of whole blood transfusions rather as blood replacement strategy than as coagulation treatment [85, 86]. This has been specifically described for soldiers in Iraq and Afghanistan with life-threatening bleedings and injuries. Survival was improved when whole blood was transfused compared to pRBCs. On the other hand, the main reason for the military is a logistic issue on the battle field which is not transferable to the logistical and distributional challenges of blood donation centers that have to guarantee nationwide blood supply in the civilian setting in advance. A recent comparison between platelet concentrates (PCs) and fresh whole blood did not provide a major advantage of whole blood versus stored thrombocytes [87]. The risk for transmission of infectious diseases or microorganisms is clearly higher when fresh whole blood is transfused. So, taken together, transfusion of fresh whole blood seems to be a reliable strategy in the military, but not in the civilian setting. There was no reduction of mortality in civilian patients with massive hemorrhage [88].Nevertheless, there is still a controversial discussion whether the imitation of whole blood in its entirety by using a fixed ratio of RBCs, FFP and PCs of 1:1:1 are superior to the hemotherapeutic policies in which blood compartments are replaced on demand by particular blood components. The answer is more than uncertain as the conventional coagulation test systems which monitor a state of not well defined 'clinical coagulopathy' did not fulfill all their expectations at bedside. As Kaufmann [80] stated in a recently published editorial, it is reasonable to regard the use of fresh whole blood as a niche product for extreme environments, and as one the benefit of which appears to be no greater than the sum of its parts. Up to now, evidence seems to increase for a higher FFP:RBC ratio while limiting crystalloids. Currently, the optimal ratio and limits opposed on crystalloid infusion have to be established by further clinical trials.

As mentioned above, the more aggressive use of FFP in massive hemorrhage has its origin in the military. However, it is currently also practiced in the civilian area. In a retrospective study of massively transfused civilian patients, Teixeira et al. [89] noted a significant reduction in mortality in those patients where FFP was transfused more aggressively. The improvement reached a plateau-like maximum at a relation of 1:3. There are several other reports with improved outcome by using increased FFP:RBC ratios varying between $1: 1$ and 1:2. There are no obviously clear-cut criteria to start with an increased ratio, which might also impose harm to patients less likely to require actually massive transfusion [33]. One strategy to identify patients who gain from this increased ratio might be the Trauma Associated Severe Hemorrhage (TASH) score [90].

There is also an interesting mathematical model to investigate the development of dilutional coagulopathy [91]. In this model a transfusion of more than 3 units of pRBCs led to a development of coagulopathy. In this model, a ratio of at least 2 FFP : 3 pRBCs was necessary to prevent the development of such kind of coagulopathy. Although there might be a trend towards more liberal use of FFP, there are well-known limitations of retrospective studies, resulting in potential survival bias. Clearly defined, blinded prospective clinical trials are urgently warranted. In trauma patients with ongoing bleedings, we recommend a fixed FFP:pRBCs ratio when the transfusion requirements exceed 4-8 units of $\mathrm{pRBC}$ in combination with an early intervention (e.g. tranexamic acid) in patients at risk for the development of trauma-induced coagulopathy.

\section{Platelets}

During acute blood loss, bone marrow and spleen release platelets into the circulation, and therefore their decrease in the peripheral blood is delayed. A sort of a reverse effect occurs after transfusion: in peripheral blood, $60-70 \%$ of transfused platelets appear only transiently over a few days in the peripheral blood, whereas one third fills up the platelet pool. Also in the field of platelet transfusions, an increased ratio of PCs to pRBCs increased 30-day survival in patients with trauma [92]. The recommendation of $1 \mathrm{pRBC}: 1 \mathrm{FFP}: 1 \mathrm{PC}$ is mainly suitable in the USA and primarily developed from the US army. This applies to platelet-rich plasma, which is different from 'high output' PCs manufactured by apheresis or pooling of 5 buffy coats mainly used in Europe. Therefore, the concentration of platelets in PCs applied in the USA is approximately one fifth of that of European preparations.

In the acute clinical situation often the question comes up when thrombocytopenia has to be expected. After massive transfusion of pRBCs and FFP exclusively (e.g. $>20$ units), a severe thrombocytopenia occurs frequently. This has been shown in the military scenario in Vietnam [93] as well as in the civilian setting [94]. The 'suspicious limit' to thrombocytopenia seems to be around 10 or $15 \mathrm{pRBCs}$, depending on the pre-injury or pre-operative status.

The standard recommendation is to keep the platelet count at least above $50,000 / \mu \mathrm{l}$ in the acute scenario. Anticipating the ongoing blood loss and the time for issuance and delivery, the order of PCs should be placed significantly earlier to keep at least the threshold of 50,000 platelet/ $\mu$ l. There are reports that a more liberal transfusion strategy of platelets might be favorable in the sense of adequate primary hemostasis and by consideration of the above mentioned delay in applying such blood components. In 132 patients with a ruptured aneurysm, a proactive intervention with a standard intervention of transfusion of 2 PCs at suspicion of rupture was followed by an improved outcome [95]. The authors confirmed their findings in a systematic review of the literature in which also a higher 
Fig. 6. Transfusion decision tree depending upon the actual/ expected degree of blood loss.

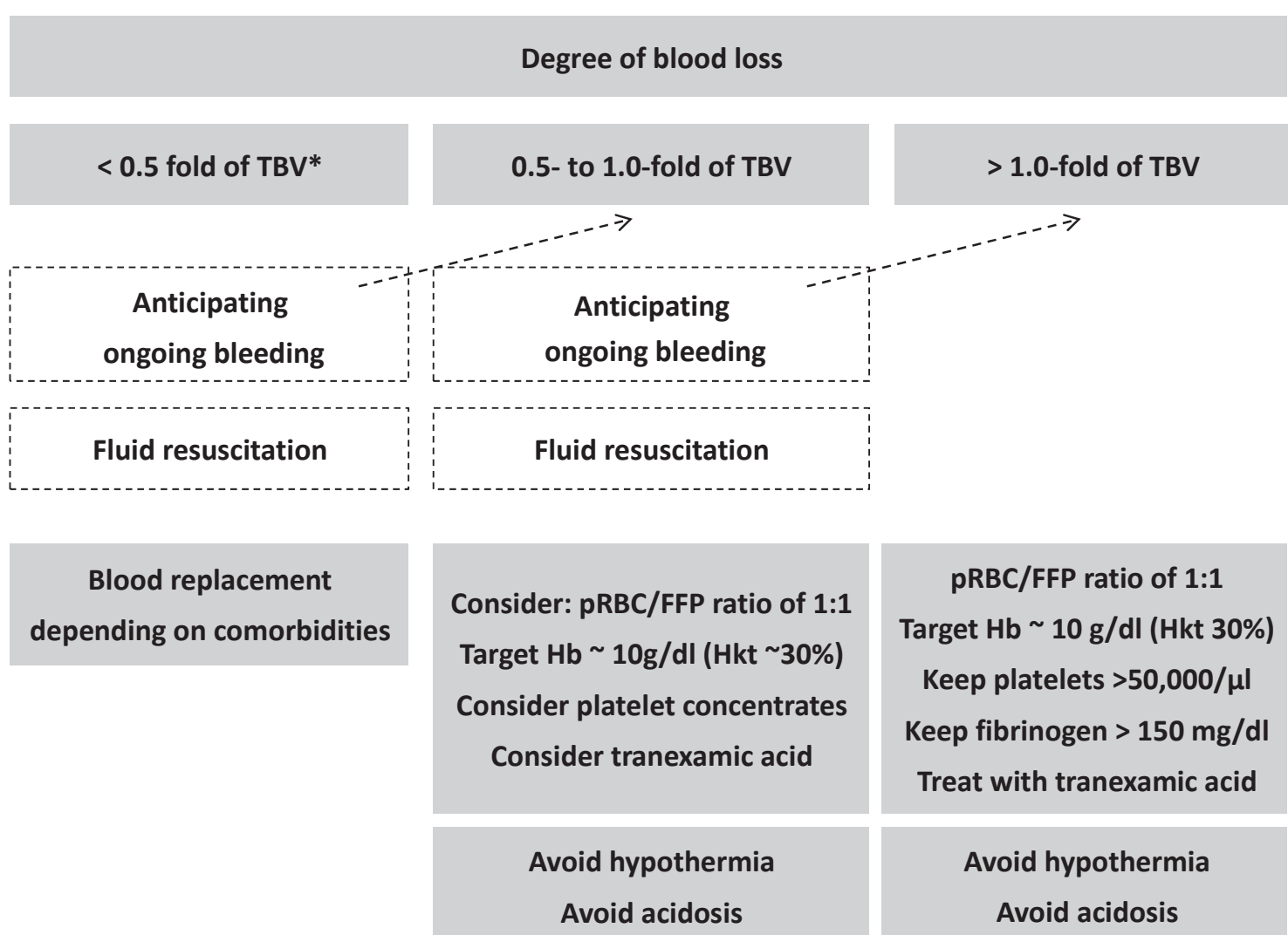

Blood replacement depending on comorbidities
pRBC/FFP ratio of 1:1

Target Hb 10 g/dl (Hkt 30\%)

Keep platelets $>50,000 / \mu \mathrm{l}$

Keep fibrinogen $>150$ mg/dl

Treat with tranexamic acid

Avoid hypothermia

Avoid acidosis

Consider rVIla treatment

if bleeding is ongoing

despite replacement therapy ratio of PCs and FFP were associated with an improved outcome [78]. On the other hand, PC application is associated with side effects and contributes to TACO.

Due to progress in noninvasive cardiovascular procedures, there is an increasing number of patients who were already receiving anticoagulatory therapy mainly targeting thrombocytes, e.g. acetylsalicic acid or glycoprotein IIb/IIIa inhibitors. In these patients, platelet transfusions (e.g. 2 units initially) are strongly advised in case of active bleeding trauma, even at higher platelet counts [96]. However, a purely prophylactic administration or a continuation after stopping the bleeding should be avoided as this might increase the rate of thrombosis in this population of patients. In the context discussed above, patients with vitamin $\mathrm{K}$ antagonists should receive 50 $\mathrm{U} / \mathrm{kg}$ body weight PCC and vitamin $\mathrm{K}$ intravenously $(10 \mathrm{mg}$ ).

A summary on the expectations and therapeutic approaches is given in figure 6 .

\section{Conclusion}

Fortunately, only a small percentage of trauma patients will require massive transfusion. However, in these patients there is a significant amount of primary trauma-induced coagulopathy which is aggravated secondarily by dilution and consumption of coagulation factors and platelets, requiring interdisciplinary teamwork in the emergency room without any delay. The implementation of a well-structured worksheet and standard operating procedures with clearly allocated tasks and therapeutic options is necessary to improve the clinical outcomes of patients with life-threating massive hemorrhage. These patients should benefit from the optimal management of fluid resuscitation, massive blood transfusion (early change to a fixed ratio of FFP:pRBCs of 1:1), and the treatment of trauma-induced coagulopathy (e.g. with tranexamic acid). The use of recombinant factor VIIa is only justified if replacement therapy of blood components and coagulation factors fail in stopping major bleedings.

\section{Disclosure Statement}

The authors did not receive any funding from any company providing products mentioned in this review. Although all statements are provided to the best of our knowledge, no guarantee or reliability is taken for their applikation in clinical practice. 


\section{References}

1 Como JJ, Dutton RP, Scalea TM, Edelman BB, Hess JR: Blood transfusion rates in the care of acute trauma. Transfusion 2004;44:809-813.

2 Committee on Trauma ACoS: The Advanced Trauma Life Support Program, Instructors Manual. Chicago, American College of Surgeons, 1988, pp 59-62.

-3 Theusinger OM, Spahn DR, Ganter MT: Transfusion in trauma: why and how should we change our current practice? Curr Opin Anaesthesiol 2009;22: 305-312.

4 Thomas D, Wee M, Clyburn P, Walker I, Brohi K, Collins P, Doughty $\mathrm{H}$, Isaac J, Mahoney PM, Shewry L: Blood transfusion and the anaesthetist: management of massive haemorrhage. Anaesthesia 2010;65:1153-1161.

5 Deutsche Gesellschaft für Unfallchirurgie e.V. (DGU): S3 - Leitlinie Polytrauma/SchwerverletztenBehandlung. Berlin, 2011. www.awmf.org/leitlinien/ detail/ll/012-019.html.

6 Bunn F, Trivedi D, Ashraf S: Colloid solutions for fluid resuscitation. Cochrane Database Syst Rev 2011;3:CD001319.

7 Garner J, Watts S, Parry C, Bird J, Cooper G Kirkman E: Prolonged permissive hypotensive resuscitation is associated with poor outcome in primary blast injury with controlled hemorrhage. Ann Surg 2010;251:1131-1139.

$\checkmark 8$ Hartog CS, Kohl M, Reinhart K: A systematic review of third-generation hydroxyethyl starch (HES 130/0.4) in resuscitation: safety not adequately addressed. Anesth Analg 2011;112:635-645.

$\checkmark$ Westphal M, James MF, Kozek-Langenecker S, Stocker R, Guidet B, Van Aken H: Hydroxyethyl starches: different products - different effects. Anesthesiology 2009;111:187-202.

10 Bickell WH, Wall MJ Jr, Pepe PE, Martin RR, Ginger VF, Allen MK, Mattox KL: Immediate versus delayed fluid resuscitation for hypotensive patients with penetrating torso injuries. N Engl J Med 1994;331:1105-1109.

11 Holcomb JB: The 2004 Fitts Lecture: current perspective on combat casualty care. J Trauma 2005;59:990-1002.

12 Li T, Zhu Y, Hu Y, Li L, Diao Y, Tang J, Liu L: Ideal permissive hypotension to resuscitate uncontrolled hemorrhagic shock and the tolerance time in rats. Anesthesiology 2011;114:111-119.

13 Stahel PF, Smith WR, Moore EE: Hypoxia and hypotension, the 'lethal duo' in traumatic brain injury: implications for prehospital care. Intensive Care Med 2008;34:402-404.

14 Ganter MT, Pittet JF: New insights into acute coagulopathy in trauma patients. Best Pract Res Clin Anaesthesiol 2010;24:15-25.

15 Esmon CT: The protein C pathway. Chest 2003; 124(3 suppl):26S-32S.

16 Rezaie AR: Vitronectin functions as a cofactor for rapid inhibition of activated protein $\mathrm{C}$ by plasminogen activator inhibitor-1. Implications for the mechanism of profibrinolytic action of activated protein C. J Biol Chem 2001;276:15567-15570.

17 Brohi K, Cohen MJ, Ganter MT, Schultz MJ, Levi M, Mackersie RC, Pittet JF: Acute coagulopathy of trauma: hypoperfusion induces systemic anticoagulation and hyperfibrinolysis. J Trauma 2008;64:12111217.

18 Cotton BA, Gunter OL, Isbell J, Au BK, Robertson AM, Morris JA Jr, St Jacques P, Young PP: Damage control hematology: the impact of a trauma exsanguination protocol on survival and blood product utilization. J Trauma 2008;64:1177-1182.
Djaldetti M, Fishman P, Bessler H, Chaimoff C: $\mathrm{pH}$-induced platelet ultrastructural alterations. A possible mechanism for impaired platelet aggregation. Arch Surg 1979;114:707-710.

20 Martini WZ: Coagulopathy by hypothermia and acidosis: mechanisms of thrombin generation and fibrinogen availability. J Trauma 2009;67:202-208.

21 Zander R: Anaemia and massive bleeding apart from the aspect of oxygenation. Wien Klin Wochenschr 2010;122(suppl 5):S6-8

22 Furie B, Furie BC: Thrombus formation in vivo. J Clin Invest 2005;115:3355-3362.

23 Lier H, Krep H, Schroeder S, Stuber F: Preconditions of hemostasis in trauma: a review. The influence of acidosis, hypocalcemia, anemia, and hypothermia on functional hemostasis in trauma. J Trauma 2008;65:951-960.

24 Zander R: Association between plasma ionized calcium and lactate concentration. Intensive Care Med 1993;19:362-363.

25 Vivien B, Langeron O, Morell E, Devilliers C, Carli PA, Coriat P, Riou B: Early hypocalcemia in severe trauma. Crit Care Med 2005;33:1946-1952. 26 Schmied H, Kurz A, Sessler DI, Kozek S, Reiter A Mild hypothermia increases blood loss and transfusion requirements during total hip arthroplasty. Lancet 1996;347:289-292.

27 Watts DD, Trask A, Soeken K, Perdue P, Dols S, Kaufmann C: Hypothermic coagulopathy in trauma: effect of varying levels of hypothermia on enzyme speed, platelet function, and fibrinolytic activity. J Trauma 1998;44:846-854

28 Wolberg AS, Meng ZH, Monroe DM 3rd, Hoffman M: A systematic evaluation of the effect of temperature on coagulation enzyme activity and platelet function. J Trauma 2004;56:1221-1228.

29 Dirkmann D, Hanke AA, Gorlinger K, Peters J: Hypothermia and acidosis synergistically impair coagulation in human whole blood. Anesth Analg 2008;106:1627-1632.

30 Meng ZH, Wolberg AS, Monroe DM 3rd, Hoffman M: The effect of temperature and $\mathrm{pH}$ on the activity of factor VIIa: implications for the efficacy of high-dose factor VIIa in hypothermic and acidotic patients. J Trauma 2003;55:886-891.

31 Keller-Stanislawski B, Lohmann A, Gunay S, Heiden M, Funk MB: The German Haemovigilance System - reports of serious adverse transfusion reactions between 1997 and 2007. Transfus Med 2009;19:340-349.

32 Silliman CC, Fung YL, Ball JB, Khan SY: Transfusion-related acute lung injury (TRALI): current concepts and misconceptions. Blood Rev 2009;23: 245-255.

33 Peiniger S, Nienaber U, Lefering R, Braun M, Wafaisade A, Wutzler S, Borgmann M, Spinella PC, Maegele M: Balanced massive transfusion ratios in multiple injury patients with traumatic brain injury. Crit Care 2011;15:R68.

34 Borgman MA, Spinella PC, Holcomb JB, Blackbourne LH, Wade CE, Lefering R, Bouillon B, Maegele M: The effect of FFP:RBC ratio on morbidity and mortality in trauma patients based on transfusion prediction score. Vox Sang 2011;101: 44-54.

35 Maegele M, Lefering R, Paffrath T, Tjardes T, Simanski C, Bouillon B: Red-blood-cell to plasma ratios transfused during massive transfusion are associated with mortality in severe multiple injury: a retrospective analysis from the Trauma Registry of the Deutsche Gesellschaft fur Unfallchirurgie. Vox Sang 2008;95:112-119.
6 Ho AM, Dion PW, Cheng CA, Karmakar MK, Cheng G, Peng Z, Ng YW: A mathematical mode for fresh frozen plasma transfusion strategies during major trauma resuscitation with ongoing hemorrhage. Can J Surg 2005;48:470-478.

37 Hiippala ST, Myllyla GJ, Vahtera EM: Hemostatic factors and replacement of major blood loss with plasma-poor red cell concentrates. Anesth Analg 1995;81:360-365.

38 Spahn DR, Cerny V, Coats TJ, Duranteau J, Fernandez-Mondejar E, Gordini G, Stahel PF, Hunt BJ, Komadina R, Neugebauer E, Ozier Y, Riddez L, Schultz A, Vincent JL, Rossaint R: Management of bleeding following major trauma: a European guideline. Crit Care 2007;11:R17.

39 Hiippala ST: Dextran and hydroxyethyl starch interfere with fibrinogen assays. Blood Coagul Fibrinolysis 1995;6:743-746.

40 Singbartl K, Innerhofer P, Radvan J, Westphalen B, Fries D, Stogbauer R, Van Aken H: Hemostasis and hemodilution: a quantitative mathematical guide for clinical practice. Anesth Analg 2003;96:929-935.

41 Meyer MA, Ostrowski SR, Windelov NA, Johansson PI: Fibrinogen concentrates for bleeding trauma patients: what is the evidence? Vox Sang 2011;101:185-190.

42 Stinger HK, Spinella PC, Perkins JG, Grathwohl KW, Salinas J, Martini WZ, Hess JR, Dubick MA Simon CD, Beekley AC, Wolf SE, Wade CE, Holcomb JB: The ratio of fibrinogen to red cells transfused affects survival in casualties receiving massive transfusions at an army combat support hospital. J Trauma 2008;64(2 suppl):S79-85.

43 Blome M, Isgro F, Kiessling AH, Skuras J, Haubelt H, Hellstern P, Saggau W: Relationship between factor XIII activity, fibrinogen, haemostasis screening tests and postoperative bleeding in cardiopulmonary bypass surgery. Thromb Haemost 2005;93: 1101-1107.

44 Charbit B, Mandelbrot L, Samain E, Baron G, Haddaoui B, Keita H, Sibony O, Mahieu-Caputo D, Hurtaud-Roux MF, Huisse MG, Denninger MH, de Prost D: The decrease of fibrinogen is an early predictor of the severity of postpartum hemorrhage. J Thromb Haemost 2007;5:266-273.

45 Huissoud C, Carrabin N, Audibert F, Levrat A, Massignon D, Berland M, Rudigoz RC: Bedside assessment of fibrinogen level in postpartum haemorrhage by thrombelastometry. BJOG 2009;116: 1097-1102.

46 Tian HL, Chen H, Wu BS, Cao HL, Xu T, Hu J, Wang G, Gao WW, Lin ZK, Chen SW: D-dimer as a predictor of progressive hemorrhagic injury in patients with traumatic brain injury: analysis of 194 cases. Neurosurg Rev 2010;33:359-365.

47 Rossaint R, Bouillon B, Cerny V, Coats TJ, Duranteau J, Fernandez-Mondejar E, Hunt BJ, Komadina R, Nardi G, Neugebauer E, Ozier Y, Riddez L, Schultz A, Stahel PF, Vincent JL, Spahn DR: Management of bleeding following major trauma: an updated European guideline. Crit Care 2010;14:R52.

487 Procoagulators. Transfus Med Hemother 2009; 36:419-436.

49 Callum JL, Karkouti K, Lin Y: Cryoprecipitate: the current state of knowledge. Transfus Med Rev 2009;23:177-88.

50 Bolliger D, Gorlinger K, Tanaka KA: Pathophysiology and treatment of coagulopathy in massive hemorrhage and hemodilution. Anesthesiology 2010;113:1205-1219.

51 Sorensen B, Bevan D: A critical evaluation of cryoprecipitate for replacement of fibrinogen. $\mathrm{Br} \mathrm{J}$ Haematol 2010;149:834-843. 
52 Levy JH, Tanaka KA, Dietrich W: Perioperative hemostatic management of patients treated with vitamin $\mathrm{K}$ antagonists. Anesthesiology 2008;109:918-926.

53 Dickneite G, Doerr B, Kaspereit F: Characterization of the coagulation deficit in porcine dilutional coagulopathy and substitution with a prothrombin complex concentrate. Anesth Analg 2008;106:1070-1077.

54 Dickneite G, Dorr B, Kaspereit F, Tanaka KA: Prothrombin complex concentrate versus recombinant factor VIIa for reversal of hemodilutional coagulopathy in a porcine trauma model. J Trauma 2010;68:1151-1157.

-55 Tanaka KA, Szlam F, Dickneite G, Levy JH: Effects of prothrombin complex concentrate and recombinant activated factor VII on vitamin $\mathrm{K}$ antagonist induced anticoagulation. Thromb Res 2008;122:117-123.

-56 Dusel CH, Grundmann C, Eich S, Seitz R, Konig $\mathrm{H}$ : Identification of prothrombin as a major thrombogenic agent in prothrombin complex concentrates. Blood Coagul Fibrinolysis 2004;15:405-411.

-57 Leissinger CA, Blatt PM, Hoots WK, Ewenstein B: Role of prothrombin complex concentrates in reversing warfarin anticoagulation: a review of the literature. Am J Hematol 2008;83:137-143.

58 Tien HC, Gough MR, Farrell R, Macdonald J: Successful use of recombinant activated coagulation factor VII in a patient with massive hemoptysis from a penetrating thoracic injury. Ann Thorac Surg 2007;84:1373-1374.

-59 Ranucci M, Isgro G, Soro G, Conti D, De Toffol B Efficacy and safety of recombinant activated factor VII in major surgical procedures: systematic review and meta-analysis of randomized clinical trials. Arch Surg 2008;143:296-304.

60 Kenet G, Walden R, Eldad A, Martinowitz U: Treatment of traumatic bleeding with recombinant factor VIIa. Lancet 1999;354:1879.

61 Mitra B, Cameron PA, Parr MJ, Phillips L: Recombinant factor VIIa in trauma patients with the 'triad of death'. Injury 2011; DOI: 10.1016/j.injury.2011.01.033.

-62 Levi M, Levy JH, Andersen HF, Truloff D: Safety of recombinant activated factor VII in randomized clinical trials. N Engl J Med 2010;363:1791-1800.

63 Spinella PC, Perkins JG, McLaughlin DF, Niles SE, Grathwohl KW, Beekley AC, Salinas J, Mehta $S$, Wade CE, Holcomb JB: The effect of recombinant activated factor VII on mortality in combatrelated casualties with severe trauma and massive transfusion. J Trauma 2008;64:286-293; discussion 293-294.

64 Ferraris VA, Brown JR, Despotis GJ, Hammon JW, Reece TB, Saha SP, Song HK, Clough ER, Shore-Lesserson LJ, Goodnough LT, Mazer CD, Shander A, Stafford-Smith M, Waters J, Baker RA, Dickinson TA, FitzGerald DJ, Likosky DS Shann KG: 2011 update to the Society of Thoracic Surgeons and the Society of Cardiovascular Anesthesiologists blood conservation clinical practice guidelines. Ann Thorac Surg 2011;91:944-982.

65 Knudson MM, Cohen MJ, Reidy R, Jaeger S, Bacchetti P, Jin C, Wade CE, Holcomb JB: Trauma, transfusions, and use of recombinant factor VIIa: a multicenter case registry report of 380 patients from the Western Trauma Association. J Am Coll Surg 2011;212:87-95.

66 Korte W: F. XIII in perioperative coagulation management. Best Pract Res Clin Anaesthesio 2010;24:85-93.
67 Mittermayr M, Streif W, Haas T, Fries D, VelikSalchner C, Klingler A, Oswald E, Bach C, Schnapka-Koepf M, Innerhofer P: Hemostatic changes after crystalloid or colloid fluid administration during major orthopedic surgery: the role of fibrinogen administration. Anesth Analg 2007;105: 905-917.

68 Marti-Fabregas J, Borrell M, Silva Y, Delgado-Mederos R, Martinez-Ramirez S, de Juan-Delago M, Tirado I, Alejaldre A, Marin R, Marti-Vilalta JL, Fontcuberta J: Hemostatic proteins and their association with hematoma growth in patients with acute intracerebral hemorrhage. Stroke 2010;41:2976-2978.

69 Potzsch B, Ivaskevicius V: Haemostasis management of massive bleeding. Hamostaseologie 2011; 31:15-20.

70 Fergusson DA, Hebert PC, Mazer CD, Fremes S, MacAdams C, Murkin JM, Teoh K, Duke PC, Arellano R, Blajchman MA, Bussieres JS, Cote D, Karski J, Martineau R, Robblee JA, Rodger M, Wells G, Clinch J, Pretorius R: A comparison of aprotinin and lysine analogues in high-risk cardiac surgery. N Engl J Med 2008;358:2319-2331.

71 Shaw AD, Stafford-Smith M, White WD, PhillipsBute B, Swaminathan M, Milano C, Welsby IJ, Aronson S, Mathew JP, Peterson ED, Newman MF: The effect of aprotinin on outcome after coronary-artery bypass grafting. N Engl J Med 2008;358:784-793.

72 Shakur H, Roberts I, Bautista R, Caballero J, Coats T, Dewan Y, El-Sayed H, Gogichaishvili T, Gupta S, Herrera J, Hunt B, Iribhogbe P, Izurieta M, Khamis H, Komolafe E, Marrero MA, MejiaMantilla J, Miranda J, Morales C, Olaomi O, Olldashi F, Perel P, Peto R, Ramana PV, Ravi RR, Yutthakasemsunt S: Effects of tranexamic acid on death, vascular occlusive events, and blood transfusion in trauma patients with significant haemorrhage (CRASH-2): a randomised, placebo-controlled trial. Lancet 2010;376:23-32.

73 Kagoma YK, Crowther MA, Douketis J, Bhandari M, Eikelboom J, Lim W: Use of antifibrinolytic therapy to reduce transfusion in patients undergoing orthopedic surgery: a systematic review of randomized trials. Thromb Res 2009;123:687-696.

74 Carless PA, Henry DA, Moxey AJ, O'Connell D, McClelland B, Henderson KM, Sly K, Laupacis A, Fergusson D: Desmopressin for minimising perioperative allogeneic blood transfusion. Cochrane Database Syst Rev 2004:CD001884.

75 Barletta JF, Cooper B, Ohlinger MJ: Adverse drug events associated with disorders of coagulation. Crit Care Med 2010;38(6 suppl):S198-218.

76 Crescenzi G, Landoni G, Biondi-Zoccai G, Pappalardo F, Nuzzi M, Bignami E, Fochi O, Maj G, Calabro MG, Ranucci M, Zangrillo A: Desmopressin reduces transfusion needs after surgery: a metaanalysis of randomized clinical trials. Anesthesiology 2008;109:1063-1076.

77 Afshari A, Wikkelso A, Brok J, Moller AM, Wetterslev J: Thrombelastography (TEG) or thromboelastometry (ROTEM) to monitor haemotherapy versus usual care in patients with massive transfusion. Cochrane Database Syst Rev 2011;3:CD007871. 78 Johansson PI, Stensballe J: Hemostatic resuscitation for massive bleeding: the paradigm of plasma and platelets - a review of the current literature. Transfusion 2010;50:701-710.

79 Carless PA, Henry DA, Carson JL, Hebert PP, McClelland B, Ker K: Transfusion thresholds and other strategies for guiding allogeneic red blood cell transfusion. Cochrane Database Syst Rev 2010: CD002042.

80 Kaufman R: A fresh take on whole blood. Transfusion 2011;51:230-233.
81 Uijttewaal WS, Nijhof EJ, Bronkhorst PJ, Den Hartog E, Heethaar RM: Near-wall excess of platelets induced by lateral migration of erythrocytes in flowing blood. Am J Physiol 1993;264:H1239-1244.

82 Valles J, Santos MT, Aznar J, Martinez M, Moscardo A, Pinon M, Broekman MJ, Marcus AJ: Platelet-erythrocyte interactions enhance alpha(IIb) beta(3) integrin receptor activation and P-selectin expression during platelet recruitment: down-regulation by aspirin ex vivo. Blood 2002;99:3978-3984.

83 AlMomani T, Udaykumar HS, Marshall JS, Chandran KB: Micro-scale dynamic simulation of erythrocyte-platelet interaction in blood flow. Ann Biomed Eng 2008;36:905-920.

84 Hardy JF, de Moerloose P, Samama CM: Massive transfusion and coagulopathy: pathophysiology and implications for clinical management. Can J Anaesth 2006;53(6 suppl):S40-58.

85 Spinella PC, Perkins JG, Grathwohl KW, Repine T, Beekley AC, Sebesta J, Jenkins D, Azarow K, Holcomb JB: Fresh whole blood transfusions in coalition military, foreign national, and enemy combatant patients during Operation Iraqi Freedom at a U.S combat support hospital. World J Surg 2008;32:2-6.

86 Spinella PC, Perkins JG, Grathwohl KW, Beekley AC, Holcomb JB: Warm fresh whole blood is independently associated with improved survival for patients with combat-related traumatic injuries. J Trauma 2009(4 suppl);66:S69-76.

87 Perkins JG, Cap AP, Spinella PC, Shorr AF, Beekley AC, Grathwohl KW, Rentas FJ, Wade CE, Holcomb JB: Comparison of platelet transfusion as fresh whole blood versus apheresis platelets for massively transfused combat trauma patients (CME). Transfusion 2011;51:242-252.

88 Ho KM, Leonard AD: Lack of effect of unrefrigerated young whole blood transfusion on patient outcomes after massive transfusion in a civilian setting. Transfusion 2011;51:1669-1675.

89 Teixeira PG, Inaba K, Shulman I, Salim A, Demetriades D, Brown C, Browder T, Green D, Rhee P: Impact of plasma transfusion in massively transfused trauma patients. J Trauma 2009;66:693-69.

90 Yucel N, Lefering R, Maegele M, Vorweg M, Tjardes T, Ruchholtz S, Neugebauer EA, Wappler F, Bouillon B, Rixen D: Trauma Associated Severe Hemorrhage (TASH)-Score: probability of mass transfusion as surrogate for life threatening hemorrhage after multiple trauma. J Trauma 2006;60:1228-1236.

91 Hirshberg A, Dugas M, Banez EI, Scott BG, Wall MJ Jr, Mattox KL: Minimizing dilutional coagulopathy in exsanguinating hemorrhage: a computer simulation. J Trauma 2003;54:454-463.

92 Holcomb JB, Wade CE, Michalek JE, Chisholm GB, Zarzabal LA, Schreiber MA, Gonzalez EA, Pomper GJ, Perkins JG, Spinella PC, Williams KL, Park MS Increased plasma and platelet to red blood cell ratios improves outcome in 466 massively transfused civilian trauma patients. Ann Surg 2008;248:447-458.

93 Miller RD: Massive blood transfusions: the impact of Vietnam military data on modern civilian transfusion medicine. Anesthesiology 2009;110:1412-1416.

94 Leslie SD, Toy PT: Laboratory hemostatic abnormalities in massively transfused patients given red blood cells and crystalloid. Am J Clin Pathol 1991;96:770-773.

95 Johansson PI, Stensballe J, Rosenberg I, Hilslov TL, Jorgensen L, Secher NH: Proactive administration of platelets and plasma for patients with a ruptured abdominal aortic aneurysm: evaluating a change in transfusion practice. Transfusion 2007;47:593-598.

96 Lecompte T, Hardy JF: Antiplatelet agents and perioperative bleeding. Can J Anaesth 2006;53 (6 suppl):S103-112. 